\title{
Trypanosoma cruzi induces changes in the nucleic acids content of host Hela cells « in vitro »
}

\author{
A. JIMENEZ-ORTIZ*, D. C. GUEVARA*, A. OSUNA-CARRILlO* and C. ALONSO**
}

\begin{abstract}
SUMMARY. The nucleic acid content of parasitized, non-parasitized Hela, cells, infected whith metacyclic forms of Trypanosoma cruzi, - was measured during 7 days of parasitization by means of histochemical techniques. Hela cells were first exposed to the parasite for $12 \mathrm{hrs}$. and then parasites were removed from the culture medium. Measurements of nuclear RNA + DNA content indicate that the three types of cells behave during 7 days of subsequent culture as three different populations. Similar results were obtained when only nuclear DNA was determined. DNA of parasitized cells increased dramatically compared to control and non-parasitized cells. This increase however was not observed in cells derived from non-parasitized cells, which were infected with trypomastigotes from the first parasitization cycle.
\end{abstract}

\section{Influence de Trypanosoma cruzi sur les acides nucléiques de la cellule hôte in vitro}

RÉSUMÉ. Les auteurs examinent à l'aide de techniques histochimiques le contenu - en acides nucléiques de cellules Hela parasitées ou non par $T$. cruzi par comparaison avec des cellules Hela cultivées en l'absence du parasite. L'étude statistique, du contenu en ARN et ADN de ces 3 populations cellulaires maintenues en culture pendant 7 jours, montre qu'elles se comportent de façon significativement différente. Des résultats comparables ont été observés lorsque seul l'ADN a été mesuré. L'ADN des cellules parasitées par $T$. cruzi augmente très sensiblement par rapport aux cellules non parasitées ou à celles n'ayant pas été en contact avec le parasite. Cela est surtout net au cours du premier cycle intracellulaire du parasite.

\section{Introduction}

Trypanosoma cruzi, a protozoon belonging to the order Kinetoplastida, constitutes the aetiological cause of Chagas Disease or American Trypanosomiasis. This protozoon has a necessary intracellular phase in vertebrate host during which its multiplication takes place. Such phase is known as the amastigote phase.

Since the initial studies by Kofoid et al. (1935), where T. cruzi was cultivated in mice fibroblasts, many investigators have studied aspects of the intracellular cycle

* Department of Parasitology, Faculty of Pharmacy, University of Granada, 18001 Granada, Spain.

** Department of Biochemistry and Molecular Biology, U.A.M., 28034 Madrid, Spain.

Accepté le 27 décembre 1983 . 
of this parasite in cells in culture. However, little work has been done on the changes produced by the parasite in the host cell. The most noticeable studies made in this field are those of Danilova and Kalinikova (1968), who examined the cytological and cytochemical changes produced by the parasite in cellular explants from carcinoma of larynx. These changes led to inhibition of the mitotic activity of the cells in culture. Bogliolo et al. (1978) indicated that certain atrophic reactions in the nuclei of parasitized Vero cells ocurred on the 5th day of culture. In previous publications, we have described the significant increase in size suffered by the nuclei of Hela cells parasitized by $T$. cruzi and reported that this increase was related to the parasite's intracellular cycle (Osuna Carrillo et al., 1980).

In the present study, we have examined by means of histochemical techniques the changes occurring in parasitized and non-parasitized cells of a culture of Hela cells, during the two first intracellular cycles of parasitization.

\section{Material and methods}

\section{Culture of Hela cells}

Hela cells were used as host cells. The cells were cultivated and maintained as single layer in $75 \mathrm{~cm}^{2}$ plastic Roux - flask at $37^{\circ} \mathrm{C}$ in MEM medium supplemented with $20 \% \mathrm{v} / \mathrm{v}$ Fetal Bovine Serum, which was previously inactivated by heat, $100 \mathrm{U} / \mathrm{ml}$ - of penicillin and $100 \mu \mathrm{g} / \mathrm{ml}$ of streptomycin.

Cells were trypsinized and resuspended in culture medium at a concentration of $1 \times 10^{6}$ cells $/ \mathrm{ml}$. They were then placed in flatbased 96 multi-well plates. A broosilicate cover-glass was previously placed in each well to act as a support for the adherence of the cells. Wells were inoculated with $0,1 \mathrm{ml}$ of cell suspension and incubated at $37^{\circ} \mathrm{C}$ in a humid atmosphere enriched with $5 \% \mathrm{CO}_{2}$ until total adherence of the cells to the glass took place.

\section{Parasites}

The strain of $T$. cruzi, isolated from a human clinical case and preserved in the Instituto de Malariología in Caracas, was kindly provided by Dr. Zozaya. The strain was maintained in our laboratory in successive stages in albino mice.

The metacyclic forms used for cell infection were obtained in vitro according to the procedure previously described by Osuna Carrillo et al. (1979).

\section{Infection of Hela cells}

Once cells had adhered to the glasses placed in the bottom of the wells of the microtiter plates, the culture medium was removed and $0,1 \mathrm{ml}$ of fresh TC 199, suplemented with $10 \% \mathrm{v} / \mathrm{v}$ FCS containing the metacyclic forms, was added to each well. The proportion of metacyclic forms per cell was 1:1.

The time of infection lasted $12 \mathrm{hrs}$. During this period the cells were incubated in a humid atmosphere with $5 \% \mathrm{CO}_{2}$ as described above at $34^{\circ} \mathrm{C}$. After the $12 \mathrm{hrs}$ 
period, the wells were washed three times with BSS Hank's solution in order to eliminate the trypanosomes which had not penetrated into the Hela cells and, after the final wash, MEM medium supplemented with $20 \% \mathrm{v} / \mathrm{v}$ FCS was added. Incubations were maintened in this medium at $37^{\circ} \mathrm{C}$ during the rest of the experiment.

The non-infected control cells were treated as the parasitized cells : that is incubated for 12 hrs. in TC $199(10 \% \mathrm{v} / \mathrm{v}$ FCS $)$ at $34^{\circ} \mathrm{C}$, washed with BBS Hank's solution and incubated in MEM $(20 \% \mathrm{v} / \mathrm{v} \mathrm{FCS})$ at $37^{\circ} \mathrm{C}$.

\section{Fixing the cover-glasses and staining}

The cells of two wells of both control and parasitized cultures were studied daily. After washing in BBS Hank's solution they were fixed for $10 \mathrm{~min}$ in ethanol (6) : choloroform (3): acid acetic (1). After fixation, slides were passed through decreasing concentrations of ethanol from $100 \%$ to $30 \%$. Finally, they were washed in deionised water in order to eliminate the fixative and to hydrate the preparations. Once the preparations had been fixed and bydrated, some of the preparations were treated for three hours at $37^{\circ} \mathrm{C}$ with Pancreatic RNase I-A (Sigma) dissolved in PBS at a concentration of $250 \mu \mathrm{g} / \mathrm{ml}$. The Pancreatic RNase was DNase-free.

After this treatment preparations were washed three times in PBS solution, once in deionised water and dried by air. Both cultures treated with RNase and those which were left untreated were stained for 72 hours at $37^{\circ} \mathrm{C}$ with Gallocyaninchromalum, Barbera et al. (1979). It has been shown that the amount of Gallocyaminchromalum bound to the nucleus after RNase extraction is proportional to the DNA content (Pagès and Alonso, 1978). After staining, the preparations were mounted on DePeX. The cytoplasm of the cells treated with RNase was free of staining.

Since the cells had not been previously synchronized with respect to DNA synthesis, the total optical densities (Do) and the maximum and minimum diameters of a large number of nuclei (300) from parasitized cells and from non-parasitized cells from the same culture were measured using a Leitz microscope (MPU-2). This operation was repeated three times for each experiment. On the other hand three determinations of optical density were performed in different areas of each nucleus, seeing that the grid of the microscope did not touch the nucleolus.

\section{Calculations and statistical approach}

The absolute quantity of Gallocyamine-chromalum staining, as an estimate of the nucleic acid content per nucleus, was calculated using the following formula :

$$
\mathrm{C}=\frac{(\mathrm{Dm} \cdot \mathrm{dm})^{2}}{4} \times \text { Do } \times \Pi
$$

$\mathrm{C}=$ nucleic acid content of the nucleus in arbitrary units (total optical density)

$\mathrm{Dm}=$ maximum diameter of the nucleus in $\mu \mathrm{m}$

$\mathrm{dm}=$ minimum diameter of the nucleus in $\mu \mathrm{m}$

Do $=$ optical density of the nucleus per $\mu \mathrm{m}^{2}$ 
The values of $\mathrm{C}$ obtained for the nucleii of each of the series of cells measured were run in a ANOVA programme using a UNIVAC II-1108 computer (tbe program was provided by the Health Science Computing [Faculty of California. Los Angeles, USA]).

\section{Results}

The results shown in Table $I$ indicate that after the first day of infection the parasitized and control cells show statistically similar values of nucleic acid content, in contrast to the non-parasitized cell population which presented significantly lower values.

Gradually, a striking increase in the quantity of nucleic acid in the population of parasitized cells was observed. This increase reached a maximum on the third day of culture, which coincides with the maximum number of intracellular amastigotes observed. On the fourth day the parasitized cells burst and a new infection took place. The nucleic acid content of the population of parasitized cells was similar to that of non-parasitized cells and to that of control cells. However the nucleic acid content of the non-parasitized cells decreased on the 5th day while that of the parasitized cells of this second parasitization cycle increased slightly. On the 7th day of culture (escape phase), the nucleic acid content of both parasitized and non-parasitized cell population, underwent a drastic decrease. Such decrease was not observed in control cells. The changes observed seem to suggest that the three types of cells (parasitized,

TABLE I. - Means values of the nucleic acid content of the nucleus from the HeLa cells parasitized by Trypanosoma cruzi, non parasitized and control cells in arbitrary units.

\begin{tabular}{ccccl}
\hline Days & $\begin{array}{c}\text { Parasitized } \\
\text { cells (I) } \\
\text { SEM }\end{array}$ & $\begin{array}{c}\text { Non parasitized } \\
\text { cells (II) } \\
\text { SEM }\end{array}$ & $\begin{array}{c}\text { Control cells (III) } \\
\text { SEM }\end{array}$ & \multicolumn{1}{c}{ Statistical level } \\
\hline 1 & $25,27 \pm 2,54$ & $15,58 \pm 1,61$ & $27,15 \pm 1,36$ & $(\mathrm{II})-(\mathrm{III})^{* *}$ \\
2 & $27,69 \pm 2,13$ & $21,38 \pm 1,52$ & $21,95 \pm 2,11$ & \\
3 & $41,01 \pm 5,22$ & $27,95 \pm 2,06$ & $33,61 \pm 2,17$ & $(\mathrm{I})-(\mathrm{II})^{* *} ;(\mathrm{I})-(\mathrm{III}) *$ \\
4 & $33,46 \pm 1,81$ & $33,40 \pm 2,50$ & $35,15 \pm 1,99$ & $(\mathrm{I})-(\mathrm{III})^{* *}$ \\
5 & $35,99 \pm 1,45$ & $22,51 \pm 1,87$ & $32,80 \pm 1,60$ & $(\mathrm{I})-(\mathrm{II})^{* *} ;(\mathrm{I})-(\mathrm{III}) *$ \\
6 & $35,21 \pm 1,58$ & $32,23 \pm 2,27$ & $23,91 \pm 1,36$ & $(\mathrm{I})-(\mathrm{III})^{* *}$ \\
7 & $12,74 \pm 1,16$ & $16,80 \pm 1,36$ & $34,30 \pm 1,70$ & $(\mathrm{I})-(\mathrm{II})^{* *} ;(\mathrm{I})-(\mathrm{III}) * *$ \\
\hline
\end{tabular}

Signification level $* * 0,001$

* 0,05

$\mathrm{SEM}=$ Standard error of the means. 
non-parasitized and control) behave, as a whole-independant of fluctuations due to the cells cycle, and as three statistically different populations, with respect to the nucleic acid content of the nucleus ( $f i g .1$ ).

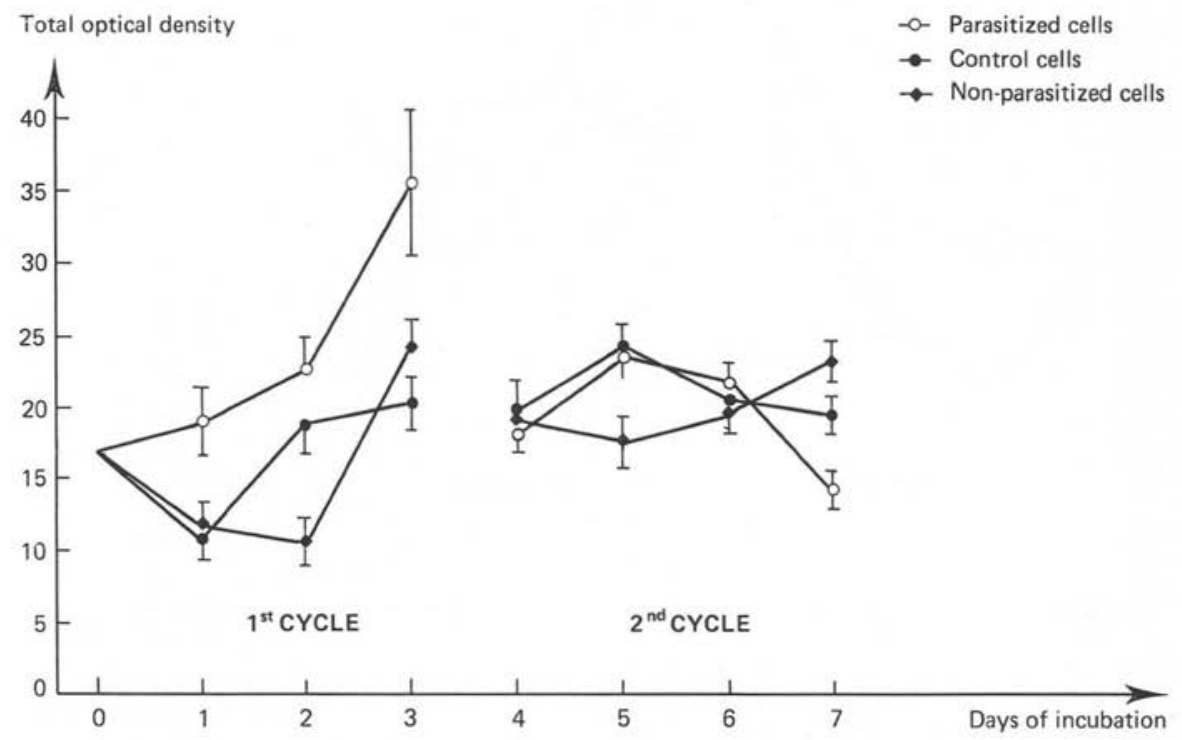

FIG. I. - Total nucleic acids content of the three cell populations. Each point represents the mean value of the optical densities of cell populations obtained in four experiments. Vertical lines represent the standard error of the mean.

\section{Cells treated with RNase}

The assumption that parasitized, non-parasitized and control cells behave as three different cell populations was confirmed by measurement of DNA. Content in DNA was determined by measuring the optical densities of Gallocyamine-chromalum stained cells previously treated with RNase (Table II, fig. 2).

After the first day of culture the amount of DNA in parasitized cells increased compared to the average values detected of day 0 (before infection), reaching maximum values on day three. However the amount of DNA in non-parasitized cells appared to be decreased on the first and second day of culture. On the third day the DNA content of non-parasitized cells strikingly increased.

As previously mentioned, at the end of the 3rd day of culture the parasitized cells burst and a new infection took place. On the 4th day of culture, the DNA content of the three cell populations (newly parasitized, non-parasitized and control cells) was statistically identical. On the fifth day, the DNA of and control cells experienced a slight increase while the DNA content of the non-parasitized cells remined practically unchanged. 


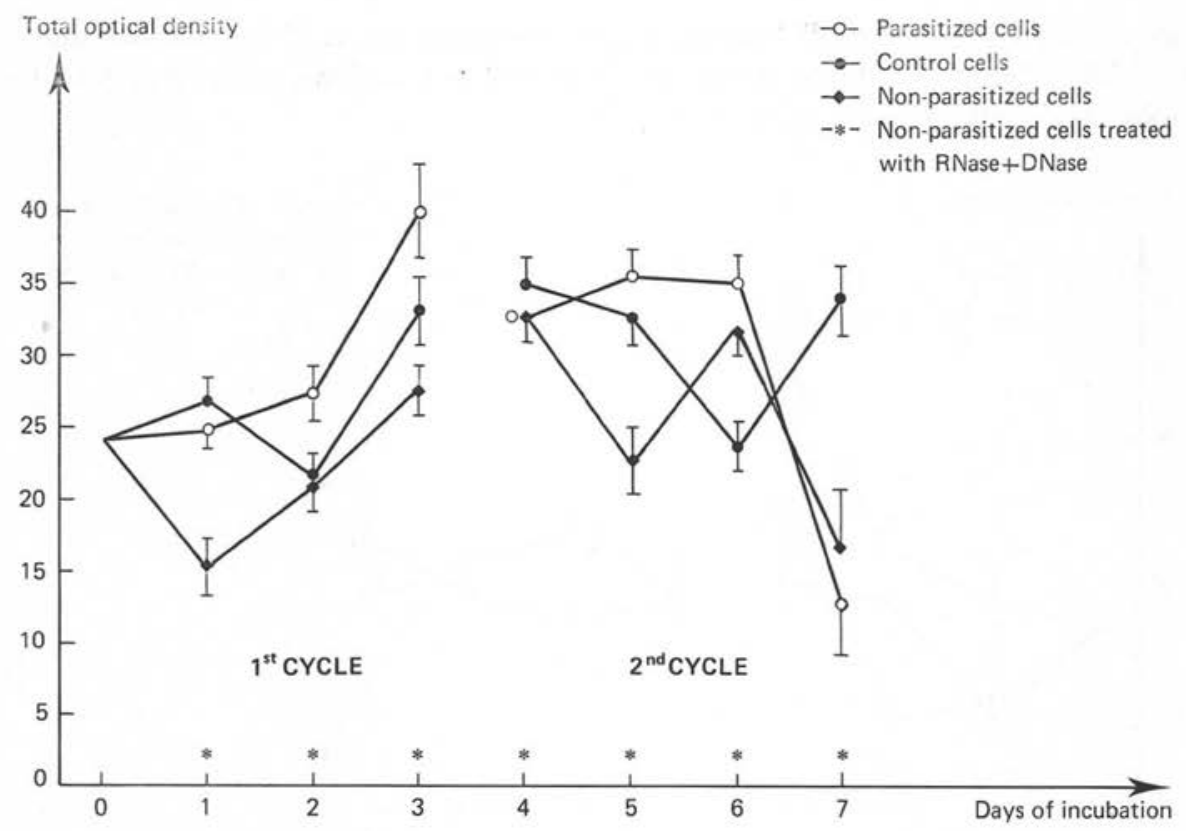

FIG. 2. - Cell populations treated with $\mathrm{RN}$-ase. Each point represents the mean value of the optical densities of cell populations obtained in four experiments. Vertical lines represents the standard error of the mean.

TABLE II. - Means values of the nucleic acid content of the nucleus from the hela cells, parasitized; non parasitized cells and control cells after the treatment with RNase.

\begin{tabular}{ccccc}
\hline Days & $\begin{array}{c}\text { Parasitized } \\
\text { cells (I) } \\
\text { SEM }\end{array}$ & $\begin{array}{c}\text { Non parasitized } \\
\text { cells (II) } \\
\text { SEM }\end{array}$ & $\begin{array}{c}\text { Control cells (III) } \\
\text { SEM }\end{array}$ & Statistical level \\
\hline 1 & $19,18 \pm 1,36$ & $11,47 \pm 1,36$ & $11,16 \pm 1,59$ & $(\mathrm{I}-\mathrm{II})^{* *} ;(\mathrm{I}-\mathrm{III})^{* *}$ \\
2 & $22,83 \pm 1,81$ & $10,77 \pm 1,72$ & $19,05 \pm 1,13$ & $(\mathrm{I}-\mathrm{II})^{* *} ;(\mathrm{II}-\mathrm{III})^{* *}$ \\
3 & $35,94 \pm 3,18$ & $24,71 \pm 1,63$ & $20,26 \pm 2,27$ & $(\mathrm{I}-\mathrm{II})^{* *} ;(\mathrm{I}-\mathrm{III})^{* *}$ \\
4 & $18,73 \pm 1,51$ & $18,91 \pm 1,77$ & $19,67 \pm 1,81$ & $(\mathrm{I}-\mathrm{II})^{*} ;(\mathrm{I}-\mathrm{III})^{*}$ \\
5 & $23,95 \pm 1,95$ & $17,86 \pm 2,36$ & $24,12 \pm 2,05$ & $(\mathrm{I}-\mathrm{III})^{*} ;(\mathrm{II}-\mathrm{III})^{*}$ \\
6 & $21,80 \pm 2,18$ & $20,00 \pm 1,81$ & $20,64 \pm 1,95$ & $(\mathrm{I}-\mathrm{II})^{*} ;(\mathrm{I}-\mathrm{III})^{* *} ;(\mathrm{II}-$ \\
& & & & III $)^{*}$ \\
7 & $14,62 \pm 3,63$ & $23,52 \pm 4,09$ & $19,45 \pm 2,36$ & $(\mathrm{I}-\mathrm{II})^{* *} ;(\mathrm{I}-\mathrm{III})^{* *}$ \\
\hline
\end{tabular}

Signification level **0,001

$\mathrm{SEM}=$ Standard error of the means 
On the 6th day of culture the average amount of DNA of parasitized, non-parasitized and control cells was statistically similar, but day 7 , the DNA of parasitized cells decreased notably, behaving as a statistically different cell population compared to control and non-parasitized cells. It is probable that such decrease is a metabolic consequence of cell death since, as has been shown previously, the nuclei of parasitized cells increase abnormaly in size at the end of each parasitization cycle. (Bogliolo et al., 1978 ; Osuna-Carrillo et al., 1980). As indicated above, the DNA measurements confirm that the three types of cells parasitized, non-parasitized and control, as a whole, behave as the three statistically different population.

\section{Discussion}

Hela cells are a transformed, very aneuploid cell line with a changeable DNA content. Nevertheless, the high amount of nuclei studied (300) homogenizes the control cell population allowing comparison with the other cell populations studied. Experiments were repeated four times in order to obtain reliable results.

The high levels of nucleic acid content of the nuclei of parasitized cells may cornelate with the increase in size of nuclei of these cells as observed by both Bogliolo et al. (1978) and Osuna-Carrillo et al. (1980). On the other hand we consider that this increase in DNA is a consecuence of parasitization, since de non-parasitized cells show, throughout the experiment, a significantly lower content in nucleic acid content than parasitized cells.

The maximum value of nucleic acid content was detected on the 3rd day of parasitization (the last day of the first intracellular cycle in our experimental conditions), which coincides with the maximum of size of nuclear areas of parasitized cells (Osuna-Carrillo et al., 1980).

At the end of the first day of culture, the non-parasitized cells and the controls experienced a significant decrease both in total nucleic acid and DNA. The amount of DNA increased thereafter in control cells while non-parasitized cells did not recover until the 3rd day reaching then values comparable to day 0 . It is possible that the decrease in DNA content at the end of the first day in control cells is due to a lag in entrance to the $\mathrm{S}$ period produced by the change from MEM $(20 \% \mathrm{FCS})$ to TC 199 $(10 \% \mathrm{FCS})$. This decrease makes the increase in DNA experienced by parasitized cells even more significant.

Second cycle parasitized cells derived from non-parasitized parent from the first cycle presented and initial increase in the content of the nucleic acid compared to that of non-parasitized cells.

However, this increase was lower than that which took place in the first intracellular parasitization cycle. It seems therefore that the infected cells (parasitized and non-parasitized), from both parasitization cycles behave differently. Since the increase in nuclear DNA is similar in parasitized cells and controls on the 5th day 
of culture, such increase can not be attributed to parasitization bur to changes in cell metabolism independent of the parasite.

Danilova and Kalinikova (1968) attributed the decrease in nucleic acid content of non-parasitized cells to the presence in the culture medium of "cruzina" which produces irreversible damage to cellular structures. We have observed similar phenomena (unpublished results), although we believe that the changes in nucleic acid content described above cannot be strictly attributed to "cruzina", since the extracellular parasites and the medium were removed after $12 \mathrm{his}$ of infection and a fiesh medium containing $20 \%$ FCS was added. It cannot be ruled out that "cruzina", excreted by the parasite during the first 12 hrs of infection interacted with nonparasitized cells so that it repressed their metabolism. If this repression took place it was, however, shut-off between the second and third day of culture. We favour the hypothesis of the liberation by parasitized cells of an inhibitory subtance(s), that affects the cellular metabolism of non-parasitized cells in culture.

Even though it is not yet well documented whether or not the interferon produced by Hela cells parasitized by T. cruzi (Rytel and Mardsen, 1968; Schmuñis et al., 1979), interferes with the nuclear metabolism of non-parasitized cells in the same culture, the liberation of interferon could explain some of our results.

It is important to notice that the population of parasitized cells from the first and second cycle of parasitization shows marked differences as can be observed in figure 1 and 2. Whether this different-behaviour is due to change in the metabolism of the parasitized cells or to differences in the trypomastigote forms from both cycles has to be investigated. It is unlikely that the differences observed between the parasitized and non-parasitized cells from the first and second cycle are due to medium exhaustion since the control cells behave normally. It should be taken into consideration however, that the newly parasitized cells derive from the non-parasitized cells from the first parasitation cycle, so that the former cells may be metabolically different from Hela cells which had never been in contact with the parasite or with parasitized cells.

Acknowledgment. We thank Dr. E. Montero for facilities in using the MPU-2 Leitz microcope. This work was supported by Comision Asesora de Investigación Científica y Técnica $(1067 / 82)$.

\section{BIBLIOGRAPHIE}

Barbera E., Caliani M. J., Pages M., Alonso C. : Chromosomal DNA denaturation and reassociation in situ. Experimental Cell Res., 1979, I19, I5I-162.

Bobliolo A. R., Guimaraes R. C., Brener Z., Golgher R., Bertelli M. M. S. : Nuclear changes in Trypanosoma cruzi parasitized cells. Rev. Inst. Med. Trop. Sao Paulo, 1978, 20, 230.

Danilova N. M., Kalinikova V. D. : Cytological and cytochemical changes of human malignant cells under the influence of infection with Trypanosoma cruzi in tissue culture (In Russian). Med. Parazitol. (Mosk.), I968, 37, 666-672.

Koford C. A., Wood F. D., Mc NeIL E. : The cycle of Trypanosoma cruzi in tissue culture of embryonic heart muscle. University of California. Publication of Zoology., I935, 4I, 23. 
Osuna Carrillo A., Jimenez Ortiz A., Lozano Maldonado J. : Medios de cultivo para la obtención de formas metaciclicas de Trypanosoma cruzi. Rev. Iber. Parasitol., 1979, 39, I 29-I33.

Osuna Carrillo A., Jimenez Ortiz A., Guevara Benitez D., Guevara Pozo D. : Cultivo in vitro de Trypanosoma cruzi sobre células Hela : Interrelaciones parásito-célula hospedadora. Rev. Iber. Parasitol., 1980, 40, 283-293.

PAges M., Alonso C. : Chemical and conformational changes in chromosome regions being actively transcribed. Nucleic Acids Res., 1978, s, 549-562.

Rytel M. W., MARSDEN P. D. : Induction of an interferonlike inhibition by Trypanosoma cruzi. Infection in mice. Am. J. Trop. Med. Hyg., I970, I9, 929-931.

Schumunis G. A., Baron S., Gonzalez-Cappa S. M., Weissenbacher N. C. : Trypanosoma cruzi as inductor of interferon. Medicina (B. Aires), 1977, 37, 429-430. 